\title{
USE OF PHOSPHITES IN POSTHARVEST TO CONTROL ANTHRACNOSE OF YELLOW PASSIONFRUIT
}

\author{
USO DE FOSFITOS EM PÓS-COLHEITA PARA O CONTROLE DA ANTRACNOSE \\ DO MARACUJÁ-AMARELO
}

\begin{abstract}
Jaqueline Barbosa DUTRA ${ }^{1}$; Luiz Eduardo Bassay BLUM ${ }^{2}$
1. Master in Plant Pathology, Departamento de Fitopatologia, Instituto de Ciências Biológicas, Universidade de Brasília, Brasília, DF, Brasil; 2. PhD. in Plant Pathology, Departamento de Fitopatologia, Instituto de Ciências Biológicas, Universidade de Brasília, Brasília, DF, Brasil, luizblum@unb.br.
\end{abstract}

\begin{abstract}
Brazil is the largest producer of yellow passionfruit (Passiflora edulis f. flavicarpa) and one of its production problems is the anthracnose (Colletotrichum spp.). The use of fungicides on control of postharvest diseases is a method that protects the fruits during storage. However, precautions must be taken due to fungicide toxicity. The restriction to the use of fungicides in post-harvest led a demand for alternative methods of disease control, and, the phosphite application is one of these methods. Therefore, this work aimed to evaluate the effects of fruit immersion in phosphite on postharvest control of anthracnose. Two tests were developed in vitro to assess the effect on the fungus: phosphite $\mathrm{Mg} 2 \quad\left(40 \% \mathrm{P}_{2} \mathrm{O}_{5}+6 \% \mathrm{Mg}\right), \mathrm{Zn}$ $\left(40 \% \mathrm{P}_{2} \mathrm{O}_{5}+10 \% \mathrm{Zn}\right), \mathrm{Ca} 1\left(30 \% \mathrm{P}_{2} \mathrm{O}_{5}+7 \% \mathrm{Ca}\right)$ and $\mathrm{K} 1\left(40 \% \mathrm{P}_{2} \mathrm{O}_{5}+20 \% \mathrm{~K}_{2} \mathrm{O}\right)$. For the in vivo tests, passionfruit (Gigante Amarelo), were wounded and inoculated $\left(50 \mu \mathrm{L} ; 10^{6}\right.$ conidia $\left.\mathrm{mL}^{-1}\right)$. Two tests were done with: $\mathrm{Cu}$ $\left(25 \% \mathrm{P}_{2} \mathrm{O}_{5}+5 \% \mathrm{Cu}\right), 2.5 \mathrm{~mL} \mathrm{~L}^{-1} ; \mathrm{Zn}, 2.5 \mathrm{~mL} \mathrm{~L}^{-1} ; \mathrm{K} 1,2.5 \mathrm{~mL} \mathrm{~L}^{-1} ; \mathrm{Mg} 1\left(30 \% \mathrm{P}_{2} \mathrm{O}_{5}+4 \% \mathrm{Mg}\right), 3 \mathrm{~mL} \mathrm{~L}^{-1} ; \mathrm{Ca} 1,3 \mathrm{~mL} \mathrm{~L}^{-1}$; $\mathrm{Ca} 2\left(10 \% \mathrm{P}_{2} \mathrm{O}_{5}+6 \% \mathrm{Ca}\right), 4 \mathrm{~mL} \mathrm{~L}^{-1} ; \mathrm{K} 2\left(40 \% \mathrm{P}_{2} \mathrm{O}_{5}+20 \% \mathrm{~K}_{2} \mathrm{O}\right), 1.5 \mathrm{~mL} \mathrm{~L}^{-1} ; \mathrm{Mg} 2\left(40 \% \mathrm{P}_{2} \mathrm{O}_{5}+6 \% \mathrm{Mg}\right), 1.5 \mathrm{~mL} \mathrm{~L}^{-1} ; \mathrm{K} 3$ $\left(20 \% \mathrm{P}_{2} \mathrm{O}_{5}+20 \% \mathrm{~K}_{2} \mathrm{O}\right) 1.75 \mathrm{~mL} \mathrm{~L}^{-1} ; \mathrm{K} 4\left(30 \% \mathrm{P}_{2} \mathrm{O}_{5}+20 \% \mathrm{~K}_{2} \mathrm{O}\right), 1.75 \mathrm{~mL} \mathrm{~L}^{-1}$. Other two tests with phosphites $\mathrm{Mg} 2$, $\mathrm{Ca} 1, \mathrm{Zn}$ and $\mathrm{K} 1$ were with $\mathrm{CaCl}_{2}(2 \%)$ was developed. In addition, phosphites were tested at 25, 50, 100 and $200 \%$ of the dose: $\mathrm{K} 2\left(100 \% ; 1.5 \mathrm{~mL} \mathrm{~L}^{-1}\right)$ and $\mathrm{Ca} 1\left(100 \% ; 3 \mathrm{~mL} \mathrm{~L}^{-1}\right)$. The phosphites Mg2, Ca1, K1 and $\mathrm{Zn}$ in vitro have reduced mycelial growth and fungus conidia production. The phosphites K1, K2, Ca1 and Zn were the ones that most reduced the size of the anthracnose lesion. There were no differences among treatments, concerning the physico-chemical fruit properties analyzed (\% fresh mass loss, total soluble solids, $\mathrm{pH}$ and titratable acidity).
\end{abstract} disease.

KEYWORDS: Alternative control of plant disease. Colletotrichum gloeosporioides. Postharvest

\section{INTRODUCTION}

The Brazilian production of yellow passionfruit (Passiflora edulis f. flavicarpa) began after 1970 (LIMA et al., 2002). Factors such as the increasing evolution of planting area and installation of juice industries, allied to excellent soil and climate conditions for the cultivation of passionfruit and the commercial acceptance of in natura fruit have made Brazil the world's largest producer of this fruit (MATTA, 2005), reaching from 823 to 840,000 tons between 2013 and 2014 (COELHO et al., 2016). Considering the world production, $97 \%$ is of yellow passionfruit, whose fruits have larger commercial importance due to the quality and industrial yield. This cultivar represents $95 \%$ of Brazilian orchards (GODOY et al., 2007).

Incorrect procedures on cultivation of yellow-passionfruit, such as the definition of point of harvest by the fall after abscission of the fruit to the ground cause friction of the fruit with the soil, damages part of the cuticle and promotes the entry of pathogens, among them the Colletotrichum gloeosporioides complex, that causes anthracnose, one of the main postharvest diseases of passionfruit (GÓES, 1998). The damage caused by the pathogen are more expressive in stablished orchards, after the first harvest, causing twig drought and plant death. The fungus infects new tissues and buds, being able to remain in a latent state, without showing any symptoms until the favorable weather and the plant suffers nutritional or water stress (JUNQUEIRA et al., 2005).

The use of fungicides against postharvest rot protects the fruits during storage. Among the fungicides used in postharvest can be cite: thiabendazole, prochloraz and imazalil (KANETIS et al., 2007), and none of these is registered in Brazil for application on passionfruit (BENATO et al., 2002). The restriction of the use of fungicides in postharvest has grown, and this fact has been led to alternative methods of disease control (SOLINO et 
Use of phosphites...

al., 2012; DUTRA et al, 2018). Among such alternatives are the phosphites, which are originated from the neutralization of $\mathrm{H}_{3} \mathrm{PO}_{3}$ for a base such as $\mathrm{KOH}$, forming the $\mathrm{KH}_{2} \mathrm{PO}_{3}$ (GÓMEZ-MERINO; TREJO-TÉLLEZ, 2015). These compounds can act directly, inhibiting mycelial growth and sporulation of the pathogen (SPOLTI et al., 2015) and indirectly, activating the plant defense mechanisms (GÓMEZ-MERINO; TREJO-TÉLLEZ, 2015). Facing this reality, the present study aimed to evaluate the effects the immersion of yellow passion fruit in phosphites solutions in postharvest on anthracnose control and fruit quality.

\section{MATERIAL AND METHODS}

The in vitro and in vivo tests were carried out in the Laboratory of Plant Pathology, and, the fruit physico-chemical analyses in the Fruit Laboratory at the University of Brasilia, DF, Brazil.

\section{Isolation of the pathogen}

Realized through the direct capture of conidia in lesions of yellow passionfruit pieces with symptoms of anthracnose. The conidia of Colletotrichum gloeosporioides were extracted from acervuli and transferred to plates with modified PDA (10g dextrose, $100 \mathrm{~g}$ potato, $20 \mathrm{~g}$ agar), with a metal-tipped sterile transfer. Such procedure was executed in aseptic air flow chamber. Plates with the fungal isolate were incubated (12h light / 15 days (d) $/ 25^{\circ} \mathrm{C}$ ) and after obtaining of pure culture and performing morphometric identification, monoconidial cultures were obtained from isolated colonies, generated by dilution plating $\left(10^{-3}-10^{-4}\right)$ of conidial suspension.

\section{Experiments in vitro}

Two trials were performed in vitro to evaluate the effects of four kinds of phosphites (Figure 1). The phosphites $\mathrm{Mg} 2\left(40 \% \mathrm{P}_{2} \mathrm{O}_{5}+6 \% \mathrm{Mg}\right)$, $\mathrm{Zn}\left(40 \% \mathrm{P}_{2} \mathrm{O}_{5}+10 \% \mathrm{Zn}\right), \mathrm{Ca} 1\left(30 \% \mathrm{P}_{2} \mathrm{O}_{5}+7 \% \mathrm{Ca}\right)$ and $\mathrm{K} 1\left(40 \% \mathrm{P}_{2} \mathrm{O}_{5}+20 \% \mathrm{~K}_{2} \mathrm{O}\right)$ were tested in 50,100 and $200 \%$ of the dose recommended. In the treatment used as control, no substance was added to the culture medium. These products were added and mixed to the medium PDA $\left(50^{\circ} \mathrm{C}\right)$ which then, was poured into Petri dishes and after $24 \mathrm{~h}$ a $3 \mathrm{~mm}$ colony disk of $C$. gloeosporioides was transferred to the center of the plate. Evaluations of the diameter of the colonies were made every $48 \mathrm{~h}$ for three weeks. At the end of the evaluation, the estimate of the number of spores per plate was made using a Neubauer Chamber.
DUTRA, J. B.; BLUM, L. E. B.

\section{Experiments in vivo}

For preparation of the pathogen inoculum was added $10 \mathrm{~mL}$ of sterile distilled water in Petri dish with a 15-day-old colony of the fungi. The conidial suspension was filtered in double layer gauze and the concentration was estimated and adjusted $\left(10^{6}\right.$ conídia $\left.\mathrm{mL}^{-1}\right)$ using a Neubauer Chamber.

Fruits of yellow passionfruit [Gigante Amarelo - Central de Abastecimento de Brasília (CEASA-DF)], were accommodated in moist chambers (Capped plastic boxes, with moistened cotton balls), kept on $25^{\circ} \mathrm{C}\left( \pm 1^{\circ} \mathrm{C}\right)$. The fruits were selected according to scale of dehydration on the stage ( $0 \%$ volume loss) and with a yellow fruit peel. The disinfection was carried out by immersing the fruits in alcohol $(10 \%, 1 \mathrm{~min})$, sodium hypochlorite $(1.0 \% ; 1 \mathrm{~min})$ followed by rinsing in sterile distilled water $(1 \mathrm{~min})$. Later, the fruits have been subjected to $2 \mathrm{~mm}$ perforations in the equatorial region, in four equidistant points. Then, $50 \mu \mathrm{L}$ of spore suspension $\left(10^{6}\right.$ conidia $\left.\mathrm{mL}^{-1}\right)$ were applied in each perforation. In the negative control treatment, sterile distilled water was applied to the wounds. After inoculation, the fruits remained for 72 hours in incubator (12h light; $\left.25^{\circ} \mathrm{C}\right)$.

Two trials with phosphites (Table 1) were done with these products: $\mathrm{Cu}\left(25 \% \mathrm{P}_{2} \mathrm{O}_{5}+5 \% \mathrm{Cu}\right)$, $2.5 \mathrm{~mL} \mathrm{~L}^{-1} ; \mathrm{Zn}\left(40 \% \mathrm{P}_{2} \mathrm{O}_{5}+10 \% \mathrm{Zn}\right), 2.5 \mathrm{~mL} \mathrm{~L}^{-1} ; \mathrm{K} 1$ $\left(40 \% \mathrm{P}_{2} \mathrm{O}_{5}+20 \% \mathrm{~K}_{2} \mathrm{O}\right), \quad 2.5 \mathrm{~mL} \quad \mathrm{~L}^{-1} ; \quad \mathrm{Mg} 1$ $\left(30 \% \mathrm{P}_{2} \mathrm{O}_{5}+4 \% \mathrm{Mg}\right), \quad 3 \mathrm{~mL} \quad \mathrm{~L}^{-1} ; \quad \mathrm{Ca} 1$ $\left(30 \% \mathrm{P}_{2} \mathrm{O}_{5}+7 \% \mathrm{Ca}\right), \quad 3 \mathrm{~mL} \quad \mathrm{~L}^{-1} ; \quad \mathrm{Ca} 2$ $\left(10 \% \mathrm{P}_{2} \mathrm{O}_{5}+6 \% \mathrm{Ca}\right), \quad 4 \mathrm{~mL} \quad \mathrm{~L}^{-1} ; \quad \mathrm{K} 2$ $\left(40 \% \mathrm{P}_{2} \mathrm{O}_{5}+20 \% \mathrm{~K}_{2} \mathrm{O}\right), \quad 1.5 \mathrm{~mL} \quad \mathrm{~L}^{-1} ; \quad \mathrm{Mg} 2$ $\left(40 \% \mathrm{P}_{2} \mathrm{O}_{5}+6 \% \mathrm{Mg}\right), \quad 1.5 \mathrm{~mL} \quad \mathrm{~L}^{-1} ; \quad \mathrm{K} 3$ $\left(20 \% \mathrm{P}_{2} \mathrm{O}_{5}+20 \% \mathrm{~K}_{2} \mathrm{O}\right), \quad 1.75 \mathrm{~mL} \quad \mathrm{~L}^{-1} ; \quad \mathrm{K} 4$ $\left(30 \% \mathrm{P}_{2} \mathrm{O}_{5}+20 \% \mathrm{~K}_{2} \mathrm{O}\right), 1.75 \mathrm{~mL} \mathrm{~L}^{-1}$. A treatment with Carbendazim $\left(1 \mathrm{~mL} \mathrm{~L}^{-1}\right)$ and other without products as control were used. Two phosphites were selected and tested at 25, 50, 100 and $200 \%$ of the recommended dose (Table 2). Such phosphites were $\mathrm{K} 2\left(40 \% \mathrm{P}_{2} \mathrm{O}_{5}+20 \% \mathrm{~K}_{2} \mathrm{O}, 100 \%, 1.5 \mathrm{~mL} \mathrm{~L}^{-1}\right)$ and $\mathrm{Ca} 1$ $\left(30 \% \mathrm{P}_{2} \mathrm{O}_{5}+7 \% \mathrm{Ca}, 100 \%, 3 \mathrm{~mL} \mathrm{~L} \mathrm{~L}^{-1}\right)$. Other two experiments with phosphites were made in combination with $\mathrm{CaCl}_{2}$ (2\%) (Table 3): $\mathrm{Mg} 2$ $\left(40 \% \mathrm{P}_{2} \mathrm{O} 5+6 \% \mathrm{Mg}\right), \quad \mathrm{Ca} 1\left(30 \% \mathrm{P}_{2} \mathrm{O}_{5}+7 \% \mathrm{Ca}\right), \quad \mathrm{Zn}$ $\left(40 \% \mathrm{P}_{2} \mathrm{O}_{5}+10 \% \mathrm{Zn}\right)$ and $\mathrm{K} 1\left(40 \% \mathrm{P}_{2} \mathrm{O}_{5}+20 \% \mathrm{~K}_{2} \mathrm{O}\right)$.

In trials with fruit, the treatments were applied by immersing them in products for $20 \mathrm{~min}$, and then, after drying of fruit $\left(25 \pm 3^{\circ} \mathrm{C}\right)$, these were placed in incubator $\left(12 \mathrm{~h} \mathrm{light;} 25^{\circ} \mathrm{C}\right)$, for 5 days. During this period, daily lesion diameter evaluations were made. For each treatment were used five inoculated and five non-inoculated fruits. All experiments were repeated once. The experimental 
Use of phosphites...

design was in complete randomized blocks with five replications in in vivo trials and four replications in the in vitro ones. The data were subjected to ANOVA and means representing de effects of the treatments were grouped by Scott-Knott's test $(\mathrm{P} \leq$ 0,05) [Assistat 7.7, (SILVA; AZEVEDO, 2016)].

\section{Fruit physico-chemical analysis}

These analyses (Normas Analíticas do Instituto Adolfo Lutz', 2005) were conducted at the end of trials and the assessed variables were:

\section{Percentage of loss of fresh mass (\%FML)}

The fruits were weighed (Digital Scale 'Filizola', BP-15) after treatment and at the end of the experiment, and, weight values were applied in the formula: $\% \mathrm{PMF}=[$ (initial mass - final mass)/initial mass] $\mathrm{x} 100$.

\section{pH}

In passionfruit sieved sample pulp, (without seeds), the $\mathrm{pH}$ (pHmetro digital 'Quimis' - Q$400 \mathrm{M} 1 / 2$ ) was determined. At the time of $\mathrm{pH}$ reading, the sample temperature was noted for subsequent correction of the total soluble solids content ( ${ }^{\circ}$ Brix).

\section{Total Soluble Solids (TSS)}

The TSS ( ${ }^{\circ}$ Brix) was determined by placing a small part of the sieved sample of fruit pulp in the prism of a hand refractometer ('Atago', N-1E).

\section{Titratable acidity (TA)}

DUTRA, J. B.; BLUM, L. E. B.

The TA (\% citric acid) was determined by diluting $5 \mathrm{~g}$ of fruit pulp in $100 \mathrm{~mL}$ of distilled water. To this sample were added $0.1 \mathrm{~mL}$ of phenolphthalein and then the titration with $\mathrm{NaOH}$ $0.1 \mathrm{~N}$ was performed. The following formula was used to calculate the $\%$ of citric acid (CA): $\% \mathrm{CA}=$ $\mathrm{Vg} \times \mathrm{N}$ x f x Eq. Ac. $/ 10$ x g, where, $\mathrm{Vg}=$ volume of $\mathrm{NaOH}(\mathrm{ml}), \mathrm{N}=$ normality of $\mathrm{NaOH}(0.1 \mathrm{~N}), \mathrm{f}=$ adjustment factor for standardization of $\mathrm{NaOH}, \mathrm{Eq}$. Ac. $=$ acid equivalent (passionfruit: 64), and, $\mathrm{g}=$ weight of the fruit sample.

\section{RESULTS AND DISCUSSION}

\section{In vitro effect of phopshites on Colletotrichum sporulation and mycelial growth}

The phosphites $\mathrm{Mg} 2\left(40 \% \mathrm{P}_{2} \mathrm{O}_{5}+6 \% \mathrm{Mg}\right)$, Cal $\left(30 \% \mathrm{P}_{2} \mathrm{O}_{5}+7 \% \mathrm{Ca}\right), \mathrm{K} 1 \quad\left(40 \% \mathrm{P}_{2} \mathrm{O}_{5}+20 \% \mathrm{~K}_{2} \mathrm{O}\right)$ and $\mathrm{Zn}\left(40 \% \mathrm{P}_{2} \mathrm{O}_{5}+10 \% \mathrm{Zn}\right)$ in vitro reduced the mycelial growth and spore production of $C$. gloeosporioides (Figure 1 A, B). Similarly, Araújo et al. (2010) reported that in in vitro conditions there was direct activity of phosphite-K on the mycelial growth of C. gloeosporioides. All phosphites tested reduced fungal mycelial growth. Conidial production was null in most treatments with these products, thus, showing an antisporulationg effect. Nojosa et al. (2005) reported in coffee (Coffea arabica) that phosphite- $\mathrm{K}\left(10 \mathrm{~mL} \mathrm{~L}^{-1}\right)$ inhibited the mycelial growth of Phoma costarricensis and reduced the length of the germinative tube. Feen and Coffey (1989), stated that the effect of phosphite-K would be as effective as fosetyl-Al due to similar mode of action.

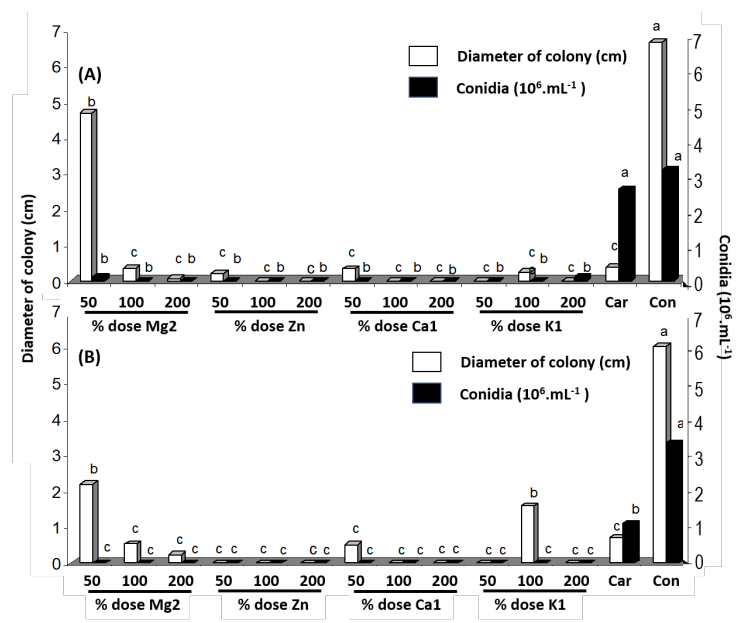

Figure 1. Effect of phosphite dose on diameter $(\mathrm{cm})$ of the colony and on Colletotrichum gloeosporioides spore concentration $\left(10^{6}\right.$ conidia $\left.\mathrm{mL}^{-1}\right)$. (A) Trial 1. (B) Trial 2. Phosphite $\mathrm{Mg} 2\left(40 \% \mathrm{P}_{2} \mathrm{O}_{5}+6 \% \mathrm{Mg}\right.$, Fitofós $\mathrm{Mg}, 100 \%, 1.5 \mathrm{~mL}$ $\left.{ }^{1}\right) ; \mathrm{Zn}\left(40 \% \mathrm{P}_{2} \mathrm{O}_{5}+10 \% \mathrm{Zn}\right.$, Phytogard $\mathrm{Zn}, 2.5 \mathrm{~mL}^{-1}$, Cal $\left(30 \% \mathrm{P}_{2} \mathrm{O}_{5}+7 \% \mathrm{Ca}\right.$, Phytogard Ca, 3mL $\left.\mathrm{mL}^{-1}\right) ; \mathrm{K} 1\left(40 \% \mathrm{P}_{2} \mathrm{O}_{5}+20 \% \mathrm{~K}_{2} \mathrm{O}\right.$, Phytogard $\left.\mathrm{K}, 2.5 \mathrm{~mL}^{-1}\right)$. Car, carbendazim. Con, control without product. Bars with the same letter in the same variable did not differ (Scott-Knott's test, $\mathrm{p} \leq 0.05$ ). 


\section{In vivo effect phosphites on passionfruit anthracnose}

Considering the average of experiments performed, all phosphites tested showed significant reduction in the size of the lesions in relation to control (Table 1). In the first experiment, the phosphites of $\mathrm{K}(1 ; 2 ; 4), \mathrm{Ca}(1 ; 2), \mathrm{Mg}(1 ; 2), \mathrm{Zn}$
DUTRA, J. B.; BLUM, L. E. B.

and $\mathrm{Cu}$ differed from control and carbendazim. In the second experiment, the phosphites of $\mathrm{Cu}$ and $\mathrm{Mg} 2$ did not differ from control. The phosphites K1, $\mathrm{K} 2, \mathrm{Ca} 1$ and $\mathrm{Zn}$ were the ones which reduced more the disease lesion size (Table 1).

Table 1. Diameter $(\mathrm{mm})$ of anthracnose lesion on yellow passionfruit inoculated with Colletotrichum gloeosporioides $\left(10^{6}\right.$ conídios $\left.\mathrm{mL}^{-1}\right)$ and submited to phosphite treatment.

\begin{tabular}{|c|c|c|c|c|c|}
\hline \multirow{2}{*}{ Treatment } & \multirow{2}{*}{$\begin{array}{l}\text { Commercial } \\
\text { (CP) }\end{array}$} & \multirow{2}{*}{$\begin{array}{l}\text { Dose } \\
\text { CP } \\
\text { mL L }^{-1}\end{array}$} & \multirow{2}{*}{\multicolumn{3}{|c|}{$\begin{array}{l}\text { Diameter of lesion }(\mathrm{mm}) \\
\text { Experiment }\end{array}$}} \\
\hline & & & & & \\
\hline No treatment & - & - & $16.2 \mathrm{a}^{1}$ & $18.0 \mathrm{a}$ & $17.1 \mathrm{a}$ \\
\hline Carbendazim & Derosal & 1.00 & $11.7 \mathrm{~b}$ & $14.3 \mathrm{a}$ & $13.0 \mathrm{~b}$ \\
\hline $\mathbf{C u}-25 \% \mathrm{P}_{2} \mathrm{O}_{5}+5 \% \mathrm{Cu}$ & Fitofós $\mathrm{Cu}$ & 2.50 & $9.7 \mathrm{c}$ & $15.7 \mathrm{a}$ & $12.7 \mathrm{~b}$ \\
\hline $\mathbf{K 3}-20 \% \mathrm{P}_{2} \mathrm{O}_{5}+20 \% \mathrm{~K}_{2} \mathrm{O}$ & Nutex Premium 00-20-20 & 1.75 & $12.7 \mathrm{~b}$ & $12.0 \mathrm{~b}$ & $12.3 \mathrm{~b}$ \\
\hline $\mathrm{Mg2}-40 \% \mathrm{P}_{2} \mathrm{O}_{5}+6 \% \mathrm{Mg}$ & Fitofós $\mathrm{Mg}$ & 1.50 & $7.8 \mathrm{c}$ & $14.2 \mathrm{a}$ & $11.0 \mathrm{c}$ \\
\hline $\mathrm{Mg1}-30 \% \mathrm{P}_{2} \mathrm{O}_{5}+4 \% \mathrm{Mg}$ & Phytogard Mg & 3.00 & $7.2 \mathrm{c}$ & $11.8 \mathrm{~b}$ & $9.5 \mathrm{~d}$ \\
\hline $\mathbf{K 4}-30 \% \mathrm{P}_{2} \mathrm{O}_{5}+20 \% \mathrm{~K}_{2} \mathrm{O}$ & Nutex Premium 00-30-20 & 1.75 & $7.7 \mathrm{c}$ & $10.8 \mathrm{~b}$ & $9.3 \mathrm{~d}$ \\
\hline Ca2 $-10 \% \mathrm{P}_{2} \mathrm{O}_{5}+6 \% \mathrm{Ca}$ & Fitofós $\mathrm{Ca}$ & 4.00 & $7.0 \mathrm{c}$ & $11.3 \mathrm{~b}$ & $9.2 \mathrm{~d}$ \\
\hline Ca1 $-30 \% \mathrm{P}_{2} \mathrm{O}_{5}+7 \% \mathrm{Ca}$ & Phytogard Ca & 3.00 & $5.5 \mathrm{c}$ & $11.5 \mathrm{~b}$ & $8.5 \mathrm{~d}$ \\
\hline $\mathbf{K 2}-40 \% \mathrm{P}_{2} \mathrm{O}_{5}+20 \% \mathrm{~K}_{2} \mathrm{O}$ & Fitofós K Plus & 1.50 & $6.0 \mathrm{c}$ & $8.3 \mathrm{~b}$ & $7.2 \mathrm{e}$ \\
\hline $\mathrm{Zn}-40 \% \mathrm{P}_{2} \mathrm{O}_{5}+10 \% \mathrm{Zn}$ & Phytogard Zn & 2.50 & $5.0 \mathrm{c}$ & $8.3 \mathrm{~b}$ & $6.7 \mathrm{e}$ \\
\hline \multirow[t]{2}{*}{$\mathbf{K 1}-40 \% \mathrm{P}_{2} \mathrm{O}_{5}+20 \% \mathrm{~K}_{2} \mathrm{O}$} & Phytogard K & 2.50 & $3.7 \mathrm{c}$ & $8.7 \mathrm{~b}$ & $6.2 \mathrm{e}$ \\
\hline & CV (\%) & - & 9.2 & 22.6 & - \\
\hline
\end{tabular}

${ }^{1}$ Values in the column with the same letters do not differ (Test of Scott-Knott, $p \leq 0,05$ ).

Some works were performed with phosphites of $\mathrm{K}$ and $\mathrm{Ca}$ (BRACKMANN et al., 2004; BRACKMANN et al., 2005; ANDREU; CALDIZ, 2006; BLUM et al., 2007; DUTRA et al, 2018), and, considering the results presented (Table 1), two experiments were carried out with dose variation of phosphites $\mathrm{K} 2 \quad\left(40 \% \mathrm{P}_{2} \mathrm{O}_{5}+20 \% \mathrm{~K}_{2} \mathrm{O}\right.$, $\left.1.5 \mathrm{~mL} . \mathrm{L}^{-1}\right)$ and $\mathrm{Ca} 1\left(30 \% \mathrm{P}_{2} \mathrm{O}_{5}+7 \% \mathrm{Ca}, 3 \mathrm{~mL} . \mathrm{L}^{-1}\right)$. Provided the average of tests, the doses of $\mathrm{Ca} 1$ and $\mathrm{K} 2$ reduced significantly the diameter of the lesion (Table 2). Observing the experiments separately only the recommended doses and twice of it, differed significantly from the inoculated control inoculada (Table 2).

Moreira et al. (2002), evaluating the effect of phosphites $(\mathrm{CaB}$ e $\mathrm{K})$ on Monilia fructicola in peach (Prunus persica), observed that the phosphite $\mathrm{K}$ provided control of $85 \%$. Blum et al. (2007) postharvest treatments on Apple have shown that with increasing doses of phosphite $\mathrm{K}$ and phosphite $\mathrm{CaB}$ reduced the incidence and the diameter of lesion caused by Penicillium expansum. However, a greater efficiency of the phosphite $\mathrm{K}$ was note in relation to the phosphite $\mathrm{CaB}$ in the control of blue mold, in the same way as observed in this study, where the phosphite $\mathrm{K} 2$ was more efficient in reducing the diameter of the anthracnose lesions in passionfruit. A difference to be noted among this study and that from Blum et al. (2007) which the fruits were immersed for $15 \mathrm{~min}$ in conidial suspensions $\left(10^{2}\right.$ conidia $\left.\mathrm{mL}^{-1}\right)$ with the tested products (phosphites and benomyl). In the present study, the passionfruits were inoculated before immersion in solutions with phosphites, in addition to the immersion time be a little bigger $(20 \mathrm{~min})$. Spolt et al. (2015) reported that phosphite K inhibits the fungi development in vitro, showing eradicating action. 
Table 2. Diameter $(\mathrm{mm})$ of anthracnose lesion on yellow passionfruit inoculated with Colletotrichum gloeosporioides $\left(10^{6}\right.$ conídios $\left.\mathrm{mL}^{-1}\right)$ and submitted to phosphite treatment.

\begin{tabular}{|c|c|c|c|c|c|c|}
\hline \multirow{3}{*}{ Treatment } & \multirow{3}{*}{$\begin{array}{l}\text { Commercial } \\
\text { Product (CP) }\end{array}$} & \multirow{3}{*}{$\begin{array}{l}\text { \% } \\
\text { Dose } \\
\text { CP }\end{array}$} & \multirow{3}{*}{$\begin{array}{l}\text { Dose } \\
\text { CP } \\
\text { mL } L^{-1}\end{array}$} & \multicolumn{3}{|c|}{ Diameter of lesion (mm) } \\
\hline & & & & \multicolumn{3}{|c|}{ Experiment } \\
\hline & & & & 1 & 2 & Mean \\
\hline No treatment & - & - & - & $20.2 \mathrm{a}^{1}$ & $15.3 \mathrm{a}$ & $17.8 \mathrm{a}$ \\
\hline Carbendazim & Derosal & $100^{2}$ & 1.00 & $17.0 \mathrm{a}$ & $15.0 \mathrm{a}$ & $16.0 \mathrm{~b}$ \\
\hline $\mathbf{K 2}-40 \% \mathrm{P}_{2} \mathrm{O}_{5}+20 \% \mathrm{~K}_{2} \mathrm{O}$ & Fitofós K Plus & 25 & 0.38 & $17.2 \mathrm{a}$ & $15.2 \mathrm{a}$ & $16.2 \mathrm{~b}$ \\
\hline $\mathbf{K 2}-40 \% \mathrm{P}_{2} \mathrm{O}_{5}+20 \% \mathrm{~K}_{2} \mathrm{O}$ & Fitofós K Plus & 50 & 0.75 & $13.7 \mathrm{~b}$ & $12.3 \mathrm{a}$ & $13.0 \mathrm{c}$ \\
\hline $\mathbf{K 2}-40 \% \mathrm{P}_{2} \mathrm{O}_{5}+20 \% \mathrm{~K}_{2} \mathrm{O}$ & Fitofós K Plus & 100 & 1.50 & $6.0 \mathrm{c}$ & $8.7 \mathrm{~b}$ & $7.3 \mathrm{~d}$ \\
\hline $\mathbf{K 2}-40 \% \mathrm{P}_{2} \mathrm{O}_{5}+20 \% \mathrm{~K}_{2} \mathrm{O}$ & Fitofós K Plus & 200 & 3.00 & $8.2 \mathrm{c}$ & $9.2 \mathrm{~b}$ & $8.7 \mathrm{~d}$ \\
\hline Ca1 $-30 \% \mathrm{P}_{2} \mathrm{O}_{5}+7 \% \mathrm{Ca}$ & Phytogard Ca & 25 & 0.75 & $13.3 \mathrm{~b}$ & $10.0 \mathrm{~b}$ & $11.7 \mathrm{c}$ \\
\hline Ca1 $-30 \% \mathrm{P}_{2} \mathrm{O}_{5}+7 \% \mathrm{Ca}$ & Phytogard Ca & 50 & 1.50 & $13.0 \mathrm{~b}$ & $12.0 \mathrm{a}$ & $12.5 \mathrm{c}$ \\
\hline Ca1 $-30 \% \mathrm{P}_{2} \mathrm{O}_{5}+7 \% \mathrm{Ca}$ & Phytogard Ca & 100 & 3.00 & $8.2 \mathrm{c}$ & $9.2 \mathrm{~b}$ & $8.7 \mathrm{~d}$ \\
\hline \multirow[t]{2}{*}{ Ca1 $-30 \% \mathrm{P}_{2} \mathrm{O}_{5}+7 \% \mathrm{Ca}$} & Phytogard Ca & 200 & 6.00 & $8.0 \mathrm{c}$ & $7.0 \mathrm{~b}$ & $7.5 \mathrm{~d}$ \\
\hline & CV (\%) & - & - & 11.1 & 17.6 & - \\
\hline
\end{tabular}

${ }^{1}$ Values in the column with the same letters do not differ (Test of Scott-Knott, $\left.\mathrm{p} \leq 0,05\right) ;{ }^{2} \%$ of dose recommended by the product producer.

Brackmann et al. (2004) reported incidence reduction of rotting apple 'Fuji' using phosphites. However, the authors reported that the $\mathrm{CaB}$ phosphite $\left(3 \mathrm{~mL} \mathrm{~L}^{-1}\right)$ did not reduce the size of the lesions, which contrasts with the results with phosphite Ca1, where the treatments with the doses of $3 \mathrm{~mL} \mathrm{~L}^{-1}$ and $6 \mathrm{~mL} \mathrm{~L}^{-1}$ phosphite Ca1 reduced the diameter of the lesion. Brackmann et al. (2004) used a differentiated method of inoculation, submerging the fruit by 20 seconds in a suspension with fungal spores, without determining the concentration of spores. The differences between the results may be related to differences in the method of inoculation.

Andreu and Caldiz (2006) assessed the phosphites $\mathrm{K}$ and $\mathrm{Ca}$ on potato (Solanum tuberosum) in the development of disease (Phytophthora infestans and Fusarium solani) right after cutting (before planting) and in foliage 35 and 66 days after the emergence of seedlings. Such authors reported differences on phosphite protection against the diseases evaluated. Plant tubers treated with phosphites $\mathrm{K}$ and $\mathrm{Ca}$ showed a reduction in the percentage of damaged area by $F$. solani, in addition to the reduction in production of protease produced by the fungus. In tubers where lesions caused by $P$. infestans were assessed, it was observed a reduction in diameter of pathogen colonies and increases in production of phytoalexins, showing that posphites can induce resistance and reduce disease. Hardy et al. (2001) indicated that phosphites may show diverse responses depending on number of aplications, dose, and stage of plant development. The phosphites $\mathrm{Zn}\left(40 \% \mathrm{P}_{2} \mathrm{O}_{5}+10 \% \mathrm{Zn}\right)$ also have their effectiveness noticed against the Asian rust (Phakopsora pachyrhizi) in soybean (Glycine max), reducing the severity of the disease (DIANESE; BLUM, 2010). Sonego et al. (2003), testing phosphite against downy mildew (Plasmopara viticola) of grapevine (Vitis vinifera), reported that phosphite $\mathrm{Zn}$ did not reduce the disease.

Table 3. Lesions diameter $(\mathrm{mm})$ in yellow-passionfruit inoculated with Colletotrichum gloeosporioides $\left(10^{6}\right.$ conidia $\left.\mathrm{mL}^{-1}\right)$ and immersed in phosphites associated or not to $\mathrm{CaCl}_{2}(2 \%)$.

\begin{tabular}{|c|c|c|c|c|c|c|}
\hline \multirow{3}{*}{ Treatment } & \multirow{3}{*}{$\begin{array}{l}\text { Comercial } \\
\text { Produto } \\
\text { (CP) }\end{array}$} & \multirow{3}{*}{$\begin{array}{l}\text { Dose } \\
\text { CP } \\
\text { mL } L^{-1}\end{array}$} & \multirow{3}{*}{$\begin{array}{l}\mathrm{CaCl}_{2} \\
2 \% \\
-\end{array}$} & \multicolumn{3}{|c|}{ Diameter of lesion (mm) } \\
\hline & & & & \multicolumn{3}{|c|}{ Experiment } \\
\hline & & & & 1 & 2 & Mean \\
\hline No treatment & - & - & - & $14.7 \mathrm{a}^{1}$ & $19.7 \mathrm{a}$ & $17.2 \mathrm{a}$ \\
\hline Carbendazim & Derosal & 1.0 & - & $11.8 \mathrm{a}$ & $17.7 \mathrm{a}$ & $14.8 \mathrm{~b}$ \\
\hline $\mathrm{Mg} 2-40 \% \mathrm{P}_{2} \mathrm{O}_{5}+6 \% \mathrm{Mg}$ & Fitofós Mg & 1.5 & - & $11.3 \mathrm{a}$ & $17.7 \mathrm{a}$ & $14.5 \mathrm{~b}$ \\
\hline Mg2 - $40 \% \mathrm{P}_{2} \mathrm{O}_{5}+6 \% \mathrm{Mg}$ & Fitofós Mg & 1.5 & + & $12.8 \mathrm{a}$ & $17.3 \mathrm{a}$ & $15.1 \mathrm{~b}$ \\
\hline $\mathrm{Zn}-40 \% \mathrm{P}_{2} \mathrm{O}_{5}+10 \% \mathrm{Zn}$ & Phytogard Zn & 2.5 & - & $8.0 \mathrm{~b}$ & $14.5 \mathrm{~b}$ & $11.3 \mathrm{c}$ \\
\hline $\mathrm{Zn}-40 \% \mathrm{P}_{2} \mathrm{O}_{5}+10 \% \mathrm{Zn}$ & Phytogard Zn & 2.5 & + & $6.7 \mathrm{~b}$ & $13.8 \mathrm{~b}$ & $10.3 \mathrm{c}$ \\
\hline $\mathrm{CaCl}_{2} 2 \%$ & - & - & + & $4.5 \mathrm{~b}$ & $13.2 \mathrm{~b}$ & $8.8 \mathrm{c}$ \\
\hline Ca1 $-30 \% \mathrm{P}_{2} \mathrm{O}_{5}+7 \% \mathrm{Ca}$ & Phytogard Ca & 3.0 & - & $6.3 \mathrm{~b}$ & $12.7 \mathrm{~b}$ & $9.5 \mathrm{c}$ \\
\hline
\end{tabular}




\begin{tabular}{lllllll}
$\mathbf{C a} 1-30 \% \mathrm{P}_{2} \mathrm{O}_{5}+7 \% \mathrm{Ca}$ & Phytogard $\mathrm{Ca}$ & 3.0 & + & $5.8 \mathrm{~b}$ & $8.2 \mathrm{c}$ & $5.7 \mathrm{~d}$ \\
$\mathrm{~K} 1-40 \% \mathrm{P}_{2} \mathrm{O}_{5}+20 \% \mathrm{~K}_{2} \mathrm{O}$ & Phytogard K & 2.5 & - & $6.8 \mathrm{~b}$ & $11.2 \mathrm{~b}$ & $9.0 \mathrm{c}$ \\
$\mathrm{K} 1-40 \% \mathrm{P}_{2} \mathrm{O}_{5}+20 \% \mathrm{~K}_{2} \mathrm{O}$ & Phytogard K & 2.5 & + & $3.7 \mathrm{~b}$ & $7.7 \mathrm{c}$ & $5.7 \mathrm{~d}$ \\
\hline & $\mathrm{CV}(\%)$ & - & - & 14.8 & 22.2 & - \\
\hline
\end{tabular}

${ }^{1}$ Values in the column with the same letters do not differ (Test of Scott-Knott, $p \leq 0,05$ ).

Phosphites alone and with $\mathrm{CaCl}_{2}$ (Table 3) [Mg2 $\left(40 \% \mathrm{P}_{2} \mathrm{O}_{5}+6 \% \mathrm{Mg}\right), \quad \mathrm{Ca} 1\left(30 \% \mathrm{P}_{2} \mathrm{O}_{5}+7 \% \mathrm{Ca}\right)$, $\mathrm{Zn} \quad\left(40 \% \mathrm{P}_{2} \mathrm{O}_{5}+10 \% \mathrm{Zn}\right)$ and $\mathrm{K} 1$ $\left.\left(40 \% \mathrm{P}_{2} \mathrm{O}_{5}+20 \% \mathrm{~K}_{2} \mathrm{O}\right)\right]$ reduced the size of anthracnose lesion. Studies have been carried out with $\mathrm{CaCl}_{2}$, investigating phosphite possible effects on fruit improvement, both in preharvest and postharvest (VIZZOTTO et al., 2002). Gorgatti Netto et al. (1996) stated that the application of Ca increases post-harvest shelf-life because it keeps the fruit firmness, reduces the respiration rate, reduces the degradation of pectins, and, reduces the incidence of diseases.

Peach fruits incorporated $\mathrm{CaCl}_{2}$ in the cell wall around the cells at the wound place, that fact reduced $34.3 \%$ of the rotten area and in $19.3 \%$ the infection by Monilinia fructicola (SOUZA et al., 2001). In studies of postharvest rot control in apples in southern Brazil, fruit treated with $\mathrm{K}$ phosphite $\left(2.5 \mathrm{~mL} \mathrm{~L}^{-1}\right)$ in association with $\mathrm{CaCl}_{2}(2 \%)$ showed lower incidence of rot and smaller diameter of lesions. These results were like those obtained with the application of standard fungicide Iprodione and above the application of phosphite $\mathrm{K}$ alone. The present study found the efficacy of phosphite $\mathrm{K}$ with $\mathrm{CaCl}_{2}$ on anthracnose reduction.

\section{Physico-chemical analysis of yellow-passionfruit}

In none of the experiments there was significant difference between the treatments and the control, when the fruit physico-chemical properties were analyzed ( $\%$ FML, TSS, $\mathrm{pH}$ and TA). Nascimento et al. (2008), studying the effect of application of different phosphites $\mathrm{K}$ in tomato, noted that there was no effect of the treatments on the total soluble solids content of these fruits. However, Albrigo (1999) reported that the use of K phosphite in pre-harvest increased the total soluble solids content of the fruit. There were no significant differences in \%FML, TSS, $\mathrm{pH}$ and TA among different treatments with and without phosphite and with and without the association of these with $\mathrm{CaCl}_{2}$ (Table 4). The values of \%FML in the control varied from 3.0 to $5.9 \%$, while in several treatments with phosphites between 2.6 and $5.9 \%$. The TSS in the control varied from 9.3 to 10.8 , while in many treatments with phosphites between 9.0 a 10.8. The TA varied from 2.1 to 2.8 in the control and from 1.9 to 2.8 in the phosphite treatments. The results for $\%$ FML (2-3.5\%) presented by Hafle et al. (2010) working with biofilm and $\mathrm{Ca}$ on yellow-passionfruit were like the ones in this work, however, TSS (14$15^{\circ}$ Brix) and TA (4.1-4.3\%) were higher. Venâncio et al. (2013) reported that besides fruit variety, the time of storage is one of the factors that affect \%FML $(0-42.8 \%)$, TSS $\left(10.5-13.3^{\circ}\right.$ Brix $)$, and AT $(3.5-5.4 \%)$.

Table 4. Physico-chemical values for $\%$ Fresh Mass Loss (FML), Total Soluble Solids (TSS $={ }^{\circ}$ Brix), $\mathrm{pH}$, Titratable Acidity ( $\mathrm{TA}=\%$ CitricAcid), of yellow-passionfruits in the different trials.

\begin{tabular}{|c|c|c|c|c|c|c|c|}
\hline Phospite & Product (CP) & СР\% & $\mathbf{m L} \mathbf{L}^{-1}$ & FML & TSS & $\mathbf{p H}$ & TA \\
\hline No treatment & - & - & - & 3.0 & 9.8 & 3.4 & 2.1 \\
\hline Carbendazim & Derosal & 100 & 1.00 & 2.5 & 9.7 & 3.4 & 2.1 \\
\hline $\mathrm{Cu} 25 \% \mathrm{P}_{2} \mathrm{O}_{5}+5 \% \mathrm{Cu}$ & Fitofós $\mathrm{Cu}$ & 100 & 2.50 & 2.9 & 9.9 & 3.4 & 1.9 \\
\hline K3 $20 \% \mathrm{P}_{2} \mathrm{O}_{5}+20 \% \mathrm{~K}_{2} \mathrm{O}$ & Nutex Premium 002020 & 100 & 1.75 & 2.6 & 10.0 & 3.5 & 2.1 \\
\hline Mg2 $40 \% \mathrm{P}_{2} \mathrm{O}_{5}+6 \% \mathrm{Mg}$ & Fitofós Mg & 100 & 1.50 & 2.7 & 10.4 & 3.2 & 2.2 \\
\hline Mg1 $30 \% \mathrm{P}_{2} \mathrm{O}_{5}+4 \% \mathrm{Mg}$ & Phytogard Mg & 100 & 3.00 & 3.2 & 10.3 & 3.3 & 2.2 \\
\hline $\mathrm{K} 430 \% \mathrm{P}_{2} \mathrm{O}_{5}+20 \% \mathrm{~K}_{2} \mathrm{O}$ & Nutex Premium 003020 & 100 & 1.75 & 3.0 & 11.4 & 3.2 & 2.1 \\
\hline Ca2 $10 \% \mathrm{P}_{2} \mathrm{O}_{5}+6 \% \mathrm{Ca}$ & Fitofós Ca & 100 & 4.00 & 3.0 & 10.6 & 3.4 & 2.1 \\
\hline Ca1 $30 \% \mathrm{P}_{2} \mathrm{O}_{5}+7 \% \mathrm{Ca}$ & Phytogard Ca & 100 & 3.00 & 3.2 & 10.7 & 3.3 & 2.0 \\
\hline $\mathbf{K 2} 40 \% \mathrm{P}_{2} \mathrm{O}_{5}+20 \% \mathrm{~K}_{2} \mathrm{O}$ & Fitofós K Plus & 100 & 1.50 & 3.9 & 10.4 & 3.3 & 2.6 \\
\hline $\mathrm{Zn} 40 \% \mathrm{P}_{2} \mathrm{O}_{5}+10 \% \mathrm{Zn}$ & Phytogard Zn & 100 & 2.50 & 3.1 & 10.0 & 3.4 & 1.9 \\
\hline \multirow[t]{2}{*}{ K1 $40 \% \mathrm{P}_{2} \mathrm{O}_{5}+20 \% \mathrm{~K}_{2} \mathrm{O}$} & Phytogard K & 100 & 2.50 & 2.9 & 10.0 & 3.4 & 1.9 \\
\hline & CV* $(\%)$ & - & - & 14.4 & 6.4 & 3.9 & 11.3 \\
\hline Phospite & Product (CP) & СР\% & $\mathbf{m L} \mathbf{L}^{-1}$ & FML & TSS & pH & TA \\
\hline
\end{tabular}




\begin{tabular}{|c|c|c|c|c|c|c|c|}
\hline No treatment & - & - & - & 4.3 & 9.3 & 3.4 & 2.4 \\
\hline Carbendazim & Derosal & 100 & 1.00 & 3.5 & 8.6 & 3.4 & 2.4 \\
\hline $\mathbf{K 2} 40 \% \mathrm{P}_{2} \mathrm{O}_{5}+20 \% \mathrm{~K}_{2} \mathrm{O}$ & Fitofós K Plus & 25 & 0.38 & 4.3 & 9.9 & 3.4 & 2.4 \\
\hline $\mathbf{K 2} 40 \% \mathrm{P}_{2} \mathrm{O}_{5}+20 \% \mathrm{~K}_{2} \mathrm{O}$ & Fitofós K Plus & 50 & 0.75 & 3.8 & 10.2 & 3.4 & 2.6 \\
\hline $\mathbf{K 2} 40 \% \mathrm{P}_{2} \mathrm{O}_{5}+20 \% \mathrm{~K}_{2} \mathrm{O}$ & Fitofós K Plus & 100 & 1.50 & 3.8 & 9.6 & 3.4 & 2.5 \\
\hline $\mathbf{K 2} 40 \% \mathrm{P}_{2} \mathrm{O}_{5}+20 \% \mathrm{~K}_{2} \mathrm{O}$ & Fitofós K Plus & 200 & 3.00 & 4.6 & 9.9 & 3.3 & 2.8 \\
\hline Ca1 $30 \% \mathrm{P}_{2} \mathrm{O}_{5}+7 \% \mathrm{Ca}$ & Phytogard Ca & 25 & 0.75 & 3.9 & 9.0 & 3.4 & 2.5 \\
\hline Ca1 $30 \% \mathrm{P}_{2} \mathrm{O}_{5}+7 \% \mathrm{Ca}$ & Phytogard Ca & 50 & 1.50 & 5.0 & 9.9 & 3.4 & 2.4 \\
\hline Ca1 $30 \% \mathrm{P}_{2} \mathrm{O}_{5}+7 \% \mathrm{Ca}$ & Phytogard Ca & 100 & 3.00 & 4.4 & 9.0 & 3.4 & 2.5 \\
\hline \multirow{2}{*}{ Ca1 $30 \% \mathrm{P}_{2} \mathrm{O}_{5}+7 \% \mathrm{Ca}$} & Phytogard Ca & 200 & 6.00 & 4.7 & 9.4 & 3.4 & 2.6 \\
\hline & CV (\%) & - & - & 21.1 & 8.7 & 2.8 & 7.7 \\
\hline Phospite $+\mathbf{C a C l}_{2}$ & Product (CP) & $\mathbf{m L} \cdot \mathbf{L}^{-1}$ & $\mathrm{CaCl}_{2}$ & FML & TSS & $\mathbf{p H}$ & TA \\
\hline No treatment & - & - & - & 5.9 & 10.8 & 3.1 & 2.8 \\
\hline Carbendazim & Derosal & 1.00 & - & 5.9 & 10.4 & 3.1 & 2.5 \\
\hline Mg2 $40 \% \mathrm{P}_{2} \mathrm{O}_{5}+6 \% \mathrm{Mg}$ & Fitofós $\mathrm{Mg}$ & 1.50 & - & 4.6 & 11.3 & 3.1 & 2,5 \\
\hline Mg2 $40 \% \mathrm{P}_{2} \mathrm{O}_{5}+6 \% \mathrm{Mg}$ & Fitofós $\mathrm{Mg}$ & 1.50 & + & 5.6 & 10.1 & 3.1 & 2.7 \\
\hline $\mathrm{CaCl}_{2} 2 \%$ & - & - & + & 4.5 & 10.7 & 3.1 & 2.8 \\
\hline $\mathrm{Zn} 40 \% \mathrm{P}_{2} \mathrm{O}_{5}+10 \% \mathrm{Zn}$ & Phytogard Zn & 2.50 & - & 5.8 & 11.1 & 2.9 & 2.5 \\
\hline $\mathrm{Zn} 40 \% \mathrm{P}_{2} \mathrm{O}_{5}+10 \% \mathrm{Zn}$ & Phytogard Zn & 2.50 & + & 5.7 & 10.8 & 3.1 & 2.7 \\
\hline Ca1 $30 \% \mathrm{P}_{2} \mathrm{O}_{5}+7 \% \mathrm{Ca}$ & Phytogard Ca & 3.00 & - & 5.9 & 10.8 & 3.0 & 2.7 \\
\hline Ca1 $30 \% \mathrm{P}_{2} \mathrm{O}_{5}+7 \% \mathrm{Ca}$ & Phytogard Ca & 3.00 & + & 4.7 & 10.2 & 3.2 & 2.6 \\
\hline $\mathrm{K1} 40 \% \mathrm{P}_{2} \mathrm{O}_{5}+20 \% \mathrm{~K}_{2} \mathrm{O}$ & Phytogard K & 2.50 & - & 5.8 & 10.5 & 3.2 & 2.8 \\
\hline \multirow[t]{2}{*}{$\mathrm{K1} 40 \% \mathrm{P}_{2} \mathrm{O}_{5}+20 \% \mathrm{~K}_{2} \mathrm{O}$} & Phytogard K & 2.50 & + & 5.7 & 10.6 & 2.9 & 2.4 \\
\hline & CV $(\%)$ & - & - & 22.7 & 8.6 & 6.8 & 9.1 \\
\hline
\end{tabular}

Cavalcante et al. (2016) found the following values of TSS, $\mathrm{pH}$ and TA for yellow-passionfrits (BRS Gigante Amarelo), respectively: $11.6\left({ }^{\circ} \mathrm{Brix}\right)$, 3.2 and 3.7. Such values were close to the ones from the present work (Table 4), and, acceptable for the industrial and fresh fruit market (GRECO et al., 2014; MOURA et al., 2016). Several studies have shown the positive effects of treatment with $\mathrm{Ca}$ in reducing respiratory rate, ethylene evolution, FML and in the maintenance of fruit organoleptic qualities (POOVAIAH, 1986). The influence of $\mathrm{CaCl}_{2}$ on the FML and the firmness of fruit-flesh was studied by Neves et al. (2004) whose reported that after immersion of 'sour carambola' ('Golden Star') in $\mathrm{CaCl}_{2}$ (1 to 4\% / $20 \mathrm{~min}$ ), there were minor FML and greater pulp-firmness in immersed fruits $(2 \%)$, and reduced spots and fruit rot. In papaya, Bicalho et al. (2000) verified that the application of $\mathrm{CaCl}_{2}(2 \%)$ was more efficient in keeping the fruit firmness than the packaging with PVC or the combination of these two treatments.

Mir et al. (1993) showed that in 'Red Delicious' apples treated with $\mathrm{CaCl}_{2}(1-4 \%$ / $5 \mathrm{~min})$ presented lower FML after $30 \mathrm{~d}$ under room conditions. Postharvest applications of $\mathrm{CaCl}_{2}$ were also studied in manga 'Julie' by Mootoo (1991). In that work, fruit immersed $\mathrm{CaCl}_{2} \quad(8 \%)$ showed superior organoleptic characteristics when compared to the control and had your storage period extended, showing less loss of fresh mass and greater retention of the coloration.

Although the alternative of applying $\mathrm{Ca}$ is debatable, due to the pre-harvest low mobility of $\mathrm{Ca}$ in the phloem and your low translocation from the application site (CHAMEL, 1989), Ferri et al. (2002) observed that the application of $\mathrm{Ca}$ at this stage, in the form of $\mathrm{CaCl}_{2}(1 \%)$ improved the conservation potential of persimmon (Diospyrus kaki) cv. Fuyu after storage in modified atmosphere had greater firmness of flesh in relation to fruit untreated with $\mathrm{CaCl}_{2}$. Vizzotto et al. (2002), assessing the influence of application of $\mathrm{Ca}$ in preservation of peach (Chiripa), found no significant differences between the fruits and plants not treated with $\mathrm{Ca}$ about firmness of flesh, TSS content, color, TA, incidence of rot, and weight loss, concluding that the $\mathrm{Ca}$ in pre-harvest treatments have no effect on the quality of this cultivar of peach.

Some authors also found that application of postharvest $\mathrm{Ca}$, cannot change some characteristics of the fruit. The content of TSS, the TA and collor of carambola (Averrhoa carambola) immersed in $\mathrm{CaCl}_{2}$ solution $(2 \% / 20 \mathrm{~min})$ showed no significant differences in relation to the control (Neves et al., 2004). In mango, Freire Jr. and Chitarra (1999) concluded that the application of $\mathrm{CaCl}_{2}$ was not effective in increasing the shelf-life of the fruit, there is no influence of it on texture, $\mathrm{pH}, \mathrm{TA}$ and 
Use of phosphites...

TSS content. In fruits of yellow-passionfruit, the results obtained in this study showed that there is no influence of $\mathrm{Ca}$ or in association with phosphites in the physico-chemical characteristics analyzed (FML, TSS, pH and TA). These results corroborate the ones observed by Silva and Vieites (2000) which, using $\mathrm{CaCl}_{2}$ (1 to 4\%) in sweet-passionfruit, submerged by 2 hours and stored under refrigeration ( $9^{\circ} \mathrm{C} ; 85-90 \% \mathrm{RH}$ ) for 30 days, observed that there was no significant effect on the FML and physicochemical characteristics of the fruit.

Fruits of yellow passion fruit, treated with different Ac source, $\mathrm{CaSO}_{4}$, showed smaller losses of fresh matter and of vitamin $\mathrm{C}$ when compared with the untreated fruits and after five weeks of storage the fruits treated showed higher levels of total acidity titratable (VIEITES; BEZERRA, 1996). Tabi et al. (2003) observed that fruits of yellow passion fruit submerged in $\mathrm{CaCl}_{2}$ solutions (1; 2\%/20 min) also showed smaller losses of fresh matter compared to untreated fruits. However, for TSS, TA, $\mathrm{pH}$ and vitamin $\mathrm{C}$, no significant difference was found between the treatments. In studies conducted by these authors, the fruits were less mature, which differs from the fruits used in the current study, where the fruits were completely yellow. Differences in maturation, as well as
DUTRA, J. B.; BLUM, L. E. B.

differences in the region of origin and cropping, among other factors, can affect the absorption of $\mathrm{Ca}$ and the response of the fruit to the nutrient (CHETTRI et al., 1991).

\section{CONCLUSIONS}

Treatments with phosphites of $\mathrm{K}$ [K1 $\left(40 \% \mathrm{P}_{2} \mathrm{O}_{5}+20 \% \mathrm{~K}_{2} \mathrm{O}\right)$ and $\mathrm{K} 2\left(40 \% \mathrm{P}_{2} \mathrm{O}_{5}+\right.$ $\left.\left.20 \% \mathrm{~K}_{2} \mathrm{O}\right)\right]$ and $\mathrm{Zn}\left(40 \% \mathrm{P}_{2} \mathrm{O}_{5}+10 \% \mathrm{Zn}\right)$ were those which showed less development of the disease. The phosphites $\mathrm{K} 1 \quad\left(40 \% \mathrm{P}_{2} \mathrm{O}_{5}+20 \% \mathrm{~K}_{2} \mathrm{O}\right), \quad \mathrm{Ca} 1$ $\left(30 \% \mathrm{P}_{2} \mathrm{O}_{5}+7 \% \mathrm{Ca}\right), \mathrm{Mg} 2\left(40 \% \mathrm{P}_{2} \mathrm{O}_{5}+6 \% \mathrm{Mg}\right)$ and $\mathrm{Zn}\left(40 \% \mathrm{P}_{2} \mathrm{O}_{5}+10 \% \mathrm{Zn}\right)$ reduced the mycelial growth and conidia production of Colletotrichum gloeosporioides in all tested doses. Treatments with phosphites and $\mathrm{CaCl}_{2}$ reduced disease. No phosphites have significantly changed the quality of fruit.

\section{ACKNOWLEDGMENTS}

The authors thank the National Council of Scientific and Technological Development (CNPq) and to the Coordination for the Improvement of Higher Education Personnel (CAPES).

RESUMO: O Brasil é o maior produtor mundial de maracujá-amarelo (Passiflora edulis f. flavicarpa) e um dos problemas para sua produção é a antracnose (Colletotrichum spp.). O uso de fungicidas no controle de doenças pós-colheita é um método que protege os frutos durante o armazenamento, mas, precauções adicionais devem ser tomadas quanto à sua toxidade, presença de resíduos e a provável seleção de fungos resistentes. A restrição ao uso de fungicidas na pós-colheita cresceu e levou à procura de alternativas de controle, e, entre tais está à aplicação de fosfitos. Diante disso, este trabalho objetivou avaliar os efeitos da imersão de frutos em soluções de fosfitos no controle da antracnose em pós-colheita. Dois testes in vitro foram feitos para avaliar o efeito de fosfito no fungo: $\mathrm{Mg} 2\left(40 \% \mathrm{P}_{2} \mathrm{O}_{5}+6 \% \mathrm{Mg}\right), \mathrm{Zn}\left(40 \% \mathrm{P}_{2} \mathrm{O}_{5}+10 \% \mathrm{Zn}\right)$, Ca1 $\left(30 \% \mathrm{P}_{2} \mathrm{O}_{5}+7 \% \mathrm{Ca}\right)$ e $\mathrm{K} 1$ $\left(40 \% \mathrm{P}_{2} \mathrm{O}_{5}+20 \% \mathrm{~K}_{2} \mathrm{O}\right)$. In vivo, frutos de maracujá (Gigante Amarelo), foram feridos e inoculados $(50 \mu \mathrm{l}$; $10^{6}$ conídios $\left.\mathrm{mL}^{-1}\right)$. Dois testes foram feitos com: $\mathrm{Cu}\left(25 \% \mathrm{P}_{2} \mathrm{O}_{5}+5 \% \mathrm{Cu}\right), 2,5 \mathrm{~mL} \mathrm{~L}^{-1} ; \mathrm{Zn}, 2,5 \mathrm{~mL} \mathrm{~L}^{-1} ; \mathrm{K} 1,2,5 \mathrm{~mL}$ $\mathrm{L}^{-1} ; \mathrm{Mg} 1 \quad\left(30 \% \mathrm{P}_{2} \mathrm{O}_{5}+4 \% \mathrm{Mg}\right), \quad 3 \mathrm{~mL} \quad \mathrm{~L}^{-1} ; \quad \mathrm{Ca} 1, \quad 3 \mathrm{~mL} \quad \mathrm{~L}^{-1} ; \quad \mathrm{Ca} 2 \quad\left(10 \% \mathrm{P}_{2} \mathrm{O}_{5}+6 \% \mathrm{Ca}\right), \quad 4 \mathrm{~mL} \quad \mathrm{~L}^{-1} ; \quad \mathrm{K} 2$ $\left(40 \% \mathrm{P}_{2} \mathrm{O}_{5}+20 \% \mathrm{~K}_{2} \mathrm{O}\right), 1,5 \mathrm{~mL} \mathrm{~L}^{-1} ; \mathrm{Mg} 2\left(40 \% \mathrm{P}_{2} \mathrm{O}_{5}+6 \% \mathrm{Mg}\right), 1,5 \mathrm{~mL} \mathrm{~L}^{-1} ; \mathrm{K} 3\left(20 \% \mathrm{P}_{2} \mathrm{O}_{5}+20 \% \mathrm{~K}_{2} \mathrm{O}\right), 1,75 \mathrm{~mL} \mathrm{~L}^{-1}$; $\mathrm{K} 4\left(30 \% \mathrm{P}_{2} \mathrm{O}_{5}+20 \% \mathrm{~K}_{2} \mathrm{O}\right), 1,75 \mathrm{~mL} \mathrm{~L}^{-1}$. Outros dois testes com fosfitos foram com $\mathrm{CaCl}_{2}(2 \%)$ e $\mathrm{Mg} 2, \mathrm{Ca} 1, \mathrm{Zn}$ e K1. Ainda, dois fosfitos foram testados a $25,50,100$ e $200 \%$ da dose: $\mathrm{K} 2\left(100 \% ; 1,5 \mathrm{~mL} \mathrm{~L}^{-1}\right)$ e Ca1 $(100 \%$; $\left.3 \mathrm{~mL} \mathrm{~L}^{-1}\right)$. Os fosfitos $\mathrm{Mg} 2$, Ca1, $\mathrm{K} 1$ e $\mathrm{Zn}$ in vitro reduziram o crescimento micelial e a produção de conídios do fungo. Os fosfitos $\mathrm{K} 1, \mathrm{~K} 2$, Ca1 e Zn foram que mais reduziram o diâmetro da lesão causada pelo patógeno. Ca1 e $\mathrm{K} 1$ com $\mathrm{CaCl}_{2}$ reduziram o tamanho das lesões. Não houve diferenças significativas entre os tratamentos, quanto as características físico-químicas analisadas (\% perda de massa fresca, teor de sólidos solúveis totais, $\mathrm{pH}$ e acidez titulável) dos frutos.

PALAVRAS-CHAVE: Controle alternativo de doenças de plantas. Colletotrichum gloeosporioides. Doenças pós-colheita. 


\section{REFERENCES}

ALBRIGO, L. G. Effects of foliar applications of urea or Nutriphite on flowering and yields of Valencia orange trees. Proceedings of the Florida State Horticultural Society, Tallahassee, v.112, p.1-4, 1999.

ANDREU A. B.; CALDIZ, D. O. El uso de fosfitos y su contribuición al control de Tizón tardio y Fusarium spp. Del campo a la fabrica, v. 6, n. 1, p. 3-6. 2006.

BENATO, E. A.; SIGRIST, J. M. M.; HANASHIRO, M. M.; MAGALHÃES, M. J. M.; BINOTTI, C. S. Avaliação de fungicidas e produtos alternativos no controle de podridões pós-colheita em maracujá-amarelo. Summa Phytopathologica, v. 28, n. 4, pp. 299-304. 2002.

BICALHO, U.O.; CHITARRA, A.B.; CHITARRA, M.I.F.; COELHO, A.H.R. Modificações texturais em mamões submetidos à aplicação pós-colheita de calcio e embalagem de PVC. Ciência e Agrotecnologia, Lavras, v. 24, n. 1, pp. 136-146. 2000.

BLUM, L. E. B.; AMARANTE, C. V. T.; DEZANET, A; LIMA, E. B.; HACK NETO, P.; ÁVILA, R. D.; SIEGA, V. Fosfitos aplicados em pós-colheita reduzem o mofo-azul em maçãs 'Fuji' e 'Gala'. Revista Brasileira de Fruticultura, Jaboticabal, v. 29, n. 2, p. 265-268. 2007. https://doi.org/10.1590/S010029452007000200015

BRACKMANN, A.; GIEHL R. F. H.; SESTARI, I.; STEFFENS, C. A. Fosfitos para o controle de podridões pós-colheita em maçãs 'Fuji' durante o armazenamento refrigerado. Ciência Rural, Santa Maria, v. 34, n. 4, p. 1039-42. 2004. http://dx.doi.org/10.1590/S0103-84782004000400011.

BRACKMANN, A.; SESTARI, I.; GIEHL R. F. H.; STEFFENS, C. A.; FAULIN, G. C.; PINTO, J. A. V. Controle de podridão pós-colheita de Penicillium spp., em maçã 'Fuji' com fosfitos e fungicidas. Revista Brasileira Agrociência, Pelotas, v. 11, n. 2, pp. 251-54. 2005. www.scielo.br/pdf/cr/v34n4/a11v34n4.pdf

CAVAlCANTE, N. R.; KRAUSE, W.; CARVAlhO, J. F.; ROCHA, M. K .P.; PALÚ, E. G.; SILVA, C. A. Productivity, fruit physicochemical quality and distinctiveness of passion fruit populations. Revista Brasileira de Fruticultura, v. 38, n. 4, e-142. 2016. https://dx.doi.org/10.1590/0100-29452016142.

CHAMEL, A. R. Permeability characteristics of isolated Golden Delicious apple fruit cuticles with regard to calcium. Journal of the Americam Society for Horticultural Science, v. 114, p. 804-809. 1989.

CHETTRI, P.; YUEN, C. M. C.; JOYCE, D.; TAN, S. C. Use of calcium to increase storage life of Keosington mangoes. In: Horticultural Research and Extension Update Conference, Mandura. Western Austrália.

Proceedings... Mandura: Departamento of Agriculture of the Western Australia University, pp. 11-14. 1991.

COELHO, E. M.; AZEVÊDO, L. C.; UMSZA-GUEZ, M. A. Fruto do maracujá: importância econômica e industrial, produção, subprodutos e prospecção tecnológica. Cadernos de Prospecção, Salvador, v. 9, n. 3, p. 323-336. 2016. https://D.O.I.: dx.doi.org/10.9771/S.CPROSP.2016.009.037

DIANESE, A. C.; BLUM, L. E. B. Uso de fosfitos no manejo de doenças fungicas de fruteiras e soja. Brasília: EMBRAPA, 2010. 29p. https://www.infoteca.cnptia.embrapa.br/bitstream/doc/902292/1/doc288.pdf

DUTRA, J. B.; BLUM, L. E. B.; LOPES, L. F.; CRUZ, A. F.; UESUGI, C. H. Use of hot water, combination of hot water and phosphite, and 1-MCP as post-harvest treatments for passion fruit (Passiflora edulis $\mathrm{f}$. flavicarpa) reduces anthracnose and does not alter fruit quality. Horticulture Environment and Biotechnology, v. 59, p. 847-856, 2018. https://link.springer.com/content/pdf/10.1007/s13580-018-0092-1.pdf https://doi.org/10.1007/s13580-018-0092-1 
FERRI, V.C.; RINALDI, M.M.; LUCHETTA, L.; ROMBALDI, V. Qualidade de caquis tratados com cálcio em pré-colheita. Revista Brasileira de Fruticultura, Jaboticabal, v.24, n.2, p.385-388. 2002. http://www.scielo.br/pdf/rbf/v24n2/a22v24n2.pdf https://doi.org/10.1590/S0100-29452002000200022

FREIRE JR., M.; CHITARRA, A.B. Efeito da aplicação de cloreto de cálcio nos frutos da manga 'Tommy Atkins' tratados hidrotermicamente. Pesquisa Agropecuária Brasileira, v.4, n.5, p.761-69. 1999. http://www.scielo.br/pdf/pab/v34n5/8421.pdf https://doi.org/10.1590/S0100-204X1999000500006

GÓMEZ-MERINO, F.C.; TREJO-TÉLLEZ, L.I. Biostimulant activity of phosphite in horticulture. Scientia Horticulturae, v. 196, p. 82-90. 2015. http://dx.doi.org/10.1016/j.scienta.2015.09.035

GORGATTI NETTO, A.; GARCIA, A.E.; ARDITO, E.F.G.; GARCIA, E.C.; BLEINROTH, E.W.; MATALLO, M.; CHITARRA, M.I.F.; BORDIN, M.R. Goiaba para exportação: procedimentos de colheita e pós-colheita. Brasília: Embrapa-SPI/Frupex, 1996. 35p. il. (Frupex. Publicações Técnicas, 20)

HARDY, G.E.S; BARRETT, S.; SHEARER B.L. The future of phosphate as a fungicide to control the soilborne plant pathogen Phytophthora cinnamoni in natural ecosystems. Australasian Plant Pathology, Orange, v. 30, p. 133-39. 2001. https://link.springer.com/content/pdf/10.1071\%2FAP01012.pdf https://doi.org/10.1071/AP01012

INSTITUTO ADOLFO LUTZ. Normas analíticas do Instituto Adolfo Lutz. Métodos físico-químicos para análise de alimentos. 4. ed. Brasília: Ministério da Saúde, Agência Nacional de Vigilância Sanitária, 2005. 1018 p. (Série A - Normas e Manuais Técnicos).

https://wp.ufpel.edu.br/nutricaobromatologia/files/2013/07/NormasADOLFOLUTZ.pdf

JUNQUEIRA, N.T.V.; BRAGA, M.F.; SHARMA, R.D.; PEIXOTO, J.R.; JUNQUEIRA, L.P. Manejo das principais doenças do maracujazeiro. In: Poltronieri L.S. et al. (Org.). Pragas e doenças de cultivos amazônicos. Belém, PA: Embrapa Amazônia Oriental. p. 157-190. 2005.

KANETIS, L.; FÖRSTER, H.; ADASKAVEG, J.E. Comparative efficacy of the new postharvest fungicides azoxystrobin, fludioxonil, and pyrimethanil for managing citrus green mold. Plant Disease, v. 91, p. 15021511. 2007. https://apsjournals.apsnet.org/doi/pdf/10.1094/PDIS-91-11-1502

LIMA, A.A.; JUNQUEIRA, N.T.V.; VERAS, M.C.M.; CUNHA, M.A.P. Tratos culturais. In: LIMA, A.A. (Ed.). Maracujá produção: aspetos técnicos. Brasília, DF: Embrapa Informação Tecnológica; Cruz das Almas: Embrapa Mandioca e Fruticultura. p. 41-48. (Frutas do Brasil, 15). 2002.

MIR, N.A.; BHAT, J.N.; BHAT, A.R. Effect of calcium infiltrations on storage behaviour of 'Red Delicious' apples. Indian Journal Plant Physiology, v. 36, n.1, p. 65-66. 1993.

MOOTOO, A. Effect of post-harvest calcium chloride dips on ripening changes in 'Julie' mangoes. Tropical Science, v. 31, n. 3, p. 243-248. 1991.

MOREIRA, L.M.; MAY-DE-MIO L.L.; VALDEBENITO-SANHUEZA, R.M.; LIMA M.L.R.Z.C.; POSSAMAI, J.C. Controle em pós-colheita de Monilinia fruticola em pêssegos. Fitopatologia Brasileira, v.27, n.4, p.395-98. 2002. http://www.scielo.br/pdf/fb/v27n4/a10v27n4.pdf https://doi.org/10.1590/S010041582002000400010

NASCIMENTO, A.R.; FERNANDES, P.M.; ROCHA, M.R.; SILVA, E.A. Fontes de fosfito e acibenzolar-smetil no controle de doenças e produtividade do tomateiro. Bioscience Journal, Uberlândia, v. 24, n.1, p.5359. 2008. http://www.seer.ufu.br/index.php/biosciencejournal/article/view/6706/4418

NEVES, C.L.; BENDER, R.J.; ROMBALDI, C.V.; VIEITES, R.L. Qualidade de carambolas azedas cv. 'Golden Star' tratadas com $\mathrm{CaCl}_{2}$ por imersão e armazenadas sobre refrigeração. Revista Brasileira de 
Fruticultura, Jaboticabal, v. 26, n.1, p. 32-35. 2004. http://www.scielo.br/pdf/rbf/v26n1/a10v26n1.pdf https://doi.org/10.1590/S0100-29452004000100010

NOJOSA, G.B.A.; RESENDE, M.L.V.; RESENDE, A.V. Uso de Fosfitos e Silicatos na Indução de Resistência. In: CAVALCANTE, L.S. (Ed.). Indução de resistência em plantas a patógenos e insetos. Piracicaba: FEALQ, p. 139-153. 2005.

POOVAIAH, B.W. Role of calcium in prolonging storage life of fruits and vegetables. Food Technology, Chicago, v. 40. n.1, p. 86-89. 1986.

SILVA, A.P.; VIEITES, R.L. Alterações nas características físicas do maracujá-doce submetido à imersão em solução de cloreto de cálcio. Ciência e Tecnologia de Alimentos, Campinas, v. 20, n. 1, p. 5-12. 2000. http://dx.doi.org/10.1590/S0101-20612000000100012

SILVA F.A.S.; AZEVEDO C.A.V. The Assistat Software Version 7.7 and its use in the analysis of experimental data. African Journal of Agricultural Research, v. 11, n.39, p.3733-3740. 2016. https://academicjournals.org/journal/AJAR/article-full-text-pdf/5E8596460818 https://doi.org/10.5897/AJAR2016.11522

SONEGO, A.R.; GARRIDO, L.R.; CZERMAINSKI, A.B.C. Avaliação de fosfitos no controle do míldio da videira. Boletim de Pesquisa e Desenvolvimento, n. 11. Bento Gonçalves: Embrapa uva e vinho, 18p. 2003.

SOUZA, A.L.B.; CHITARRA, M.I.F.; CHITARRA, A.B.; MACHADO, J.C. Efeito do Cálcio na cura de ferimento e na resistência de pêssego ao ataque de Monilinia fruticola (Wint.) Honey. Ciência e Agrotecnologia, Lavras, v. 25, n. 3, p. 616-24. 2001.

SPOLTI, P.; VALDEBENITO-SANHUEZA, R.M.; CAMPOS, A.D.; DEL PONTE, E.M. Modo de ação de fosfitos de potássio no controle da podridão olho de boi em maçã. Summa Phytopathologica, v.41, n.1, p.4248, 2015. http://www.scielo.br/pdf/sp/v41n1/0100-5405-sp-41-01-00042.pdf https://doi.org/10.1590/0100$5405 / 1982$

VIEITES, R.L.; BEZERRA L.P. Efeito do sulfato de cálcio e da embalagem de polietileno, na conservação de maracujá amarelo, armazenado em condições de refrigeração. Revista Brasileira de Fruticultura, Cruz das Almas, v. 18, n. 2, p. 235-243. 1996.

VIZZOTTO, M.; ANTUNES, P.L.; BRACKMANN, A.; DALBOSCO, V. Aplicação de Cálcio em pré-colheita na conservação de pêssego [Prunus persica (L.) Batsch.], cv. Chiripá. Revista Brasileira de Agrociência, v. 8, n.1, p. 31-35. 2002. 